\title{
PENGEMBANGAN MEDIA PEMBELAJARAN APRON HITUNG UNTUK MENINGKATKAN KEMAMPUAN BERHITUNG ANAK
}

\author{
Germana Due ${ }^{1}$, Efrida Ita ${ }^{2}$ \\ Sekolah Tinggi Keguruan dan Ilmu Pendidikan Citra Bakti Flores, Nusa Tenggara Timur, Indonesia \\ Email.germanadue@gmail.com
}

\begin{abstract}
The problem found in this study is the lack of supportive learning media in the learning process of children in accordance with the characteristics of children in cognitive development related to the ability to count at early childhood. This study aims to: (1) produce a count apron media that fits the characteristics of children in group B of Citra Bakti Terpadu early childhood education, (2) find out the design of the count apron learning media in improving the numeracy skill at early childhood in group B Citra Bakti Terpadu early childhood education. This studywasthe development research using ADDIE model which consisted of five stages namely Analysis, Design, Develop, Implement and Evaluate. The methods used in this study were the observation, the interview, the questionnaire, and the documentation methods. The study instrumentswerethe observation, interview, questionnaire and documentation guidesregarding the learning objectives of cognitive aspect. The results of the development research show that from the validation of the material expert with the results of the assessment conducted by the material expert gets a score of $100 \%$ with the category "very valid", the assessment by the media expert achieves a score of $100 \%$ with the category "very valid", the assessment conducted by the learning design expert gets a score of $100 \%$ with the category "very valid", and the result of individual test conducted on two students of group B Citra Bakti Terpadu early childhood educationgets a score of 100\% with the category "very valid" and small group test on five students gets a score of $100 \%$ with the category "very valid". Thus, the development of count apron learning media to improve numeracy skillat early childhood in group B of Citra Bakti Terpaduearly childhood education is worthy to be used.
\end{abstract}

Keywords: Counting, Cognitive Ability, Media Apron Count.

\begin{abstract}
Abstrak
Masalah yang ditemukan dalam penelitian ini adalah kurangnya mediapembelajaran yang mendukung dalam proses belajar anak sesuai dengan karakteristik anak dalam perkembangan kognitif yang berkaitan dengan kemampuan berhitung pada anak usia dini. Penelitian ini bertujuan untuk: (1) menghasilkan media apron hitung yang sesuai dengan karakteristik anak di kelompok B PAUD Terpadu Citra Bakti, (2) mengetahui desain media pembelajaran apron hitung untuk meningkatkan kemampuan berhitung pada anak usia dini di kelompok B PAUD Terpadu Citra Bakti. Penelitian ini adalah penelitian pengembangan dengan menggunakan model ADDIE yang terdiri dari lima tahap yakni Analysis, Design, Develop, Implement and Evaluate. Metode yang digunakan dalam penelitian ini adalah metode observasi, metode wawancara, metode angket, dan metode dokumentasi. Instrumen penelitian ini adalah panduan observasi, wawancara, angket dan dokumentasi mengenai tujuan pembelajaran aspek kognitif. Hasil penelitian pengembangan menunjukkan bahwa dari validasi ahli materi dengan hasil penilaian yang dilakukan oleh ahli materi mendapatkan skor $100 \%$ dengan kategori "sangat valid", penilaian oleh ahli media mendapatkan skor $100 \%$ dengan kategori "sangat valid", penilaian yang dilakukan oleh ahli desain pembelajaran mendapatkan skor $100 \%$ dengan kategori "sangat valid", serta hasil uji coba perorangan yang dilakukan pada dua orang siswa kelompok B PAUD Terpadu Citra Bakti mendapatkan skor 100\% dengan kategori "sangat valid" dan uji coba kelompok kecil pada lima orang siswa mendapat skor $100 \%$ dengan kategori "sangat valid." Dengan demikian, pengembangan media pembelajaran apron hitung untuk meningkatkan kemampuan berhitung pada anak usia dini di kelompok B PAUD Terpadu Citra Bakti layak untuk digunakan.
\end{abstract}

Kata Kunci: Berhitung, Kemampuan Kognitif, Media Apron Hitung. 


\section{PENDAHULUAN}

Undang-Undang Nomor 20 Tahun 2003 tentang Sistem Pendidikan Nasional menjelaskan bahwa pendidikan adalah usaha sadar dan terencana untuk mewujudkan suasana belajar dan proses pembelajaran agar peserta didik secara aktif mengembangkan potensi dirinya untuk memiliki kekuatan spiritual keagamaan, pengendalian diri, kepribadian, kecerdasan, akhlak mulia, serta keterampilan yang diperlukan dirinya, masyarakat, bangsa, dan negara. Semua orang berhak mendapatkan pendidikan, tidak terkecuali bagi anak usia dini dari berbagai daerah, suku, ras, dan agama melalui pendidikan dasar yaitu Pendidikan Anak Usia Dini (PAUD). Karena anak adalah salah satu bagian terpenting dalam komponen masyarakat Indonesia. Anak adalah pemilik masa kini dan masa depan bangsa sekaligus pemilik bangsa, karena di tangan merekalah diteruskan sejarah kehidupan manusia Indonesia selanjutnya (Efrida Ita, 2018).

Berdasarkan Permendikbud No. 146 Tahun 2014 dengan kajian khusus pada aspek kognitif dalam Standar Nasional PAUD No. 137 yang memuat tentang Standar Tingkat Pencapaian Perkembangan Anak (STPPA) dinyatakan bahwa berbagai stimulasi pendidikan yang diberikan oleh orang-orang dewasa di sekitar anak pada masa emas tersebut dapat memberikan pengaruh dan fondasi kuat terhadap aspek-aspek perkembangan anak sehingga pertumbuhan dan perkembangan anak dapat terasah secara optimal. Oleh karena itu, pertumbuhan dan perkembangan anak yang berkualitas tergantung pada cara atau upaya orang tua dan pendidik serta orang dewasa di sekitar anak yang mampu memberikan rangsangan pendidikan sesuai dengan tingkat usia anak. Salah satu aspek perkembangan yang harus diasah sejak dini adalah aspek kemampuan kognitif anak.

Kemampuan kognitif ialah sesuatu yang fundamental yang terletak pada pemahaman bagaimana suatu proses berpikir anak dalam menghubungkan, menilai, dan mempertimbangkan suatu peristiwa. Aspek perkembangan kognitif meliputi akal dan pikiran manusia yang harus dikembangkan beriringan dengan kemampuan lainnya (Suyanto, 2005). Keterkaitan antara aspek perkembangan yang satu dengan lainnya memiliki hubungan erat, baik aspek perkembangan intelektual, emosional, 
sosial maupun fisik. Dengan demikian, setiap kegiatan stimulasi yang diberikan dapat mengasah dan meningkatkan salah satu atau lebih aspek perkembangan atau kemampuan dasar anak.

Mengacu pada hasil observasi yang dilakukan di Kelompok B PAUD Terpadu Citra Bakti diperoleh data bahwa kemampuan berhitung anak masih rendah. Hal tersebut dapat dilihat pada saat kegiatan pembelajaran berhitung berlangsung di Kelompok B PAUD Terpadu Citra Bakti yakni guru menggunakan Lembar Kerja Anak (LKA) dengan meminta anak untuk mengerjakan LKA tersebut dengan terlebih dahulu diberi contoh oleh guru di papan tulis, sehingga rasa bosan dirasakan oleh anak dalam kegiatan pembelajaran di dalam kelas. Kegiatan tersebut mengakibatkan perhatian anak tidak terfokus pada apa yang disampaikan oleh guru sehingga anak memiliki tendensi untuk bermain bersama teman semejanya.

Kemampuan berhitung sangat penting untuk diperkenalkan pada anak sejak dini. Mengingat hal tersebut penting, maka penggunaan metode dan strategi yang tepat dalam pembelajaran berhitung harus diperhatikan (Hamruni Yuliani, 2014). Sebelum mengajarkan hal tersebut kepada anak, orang tua dan guru hendaknya terlebih dahulu mengerti untuk apa matematika diajarkan kepada anak. Apabila bertujuan untuk membuat anak senang menghitung sejak dini, maka salah satu cara yang dapat dilakukan adalah dengan mengenalkan konsep bilangan banyak sedikit dan besar kecil menggunakan benda-benda konkrit sebagai sumber belajar.

Pembelajaran yang menggembirakan bagi anak perlu disiapkan sebaik mungkin agar anak senang dalam mengikuti proses pembelajaran. Dalam kondisi senang anak akan belajar dengan baik dan optimal. Prinsip belajar di PAUD yaitu belajar sambil bermain atau belajar seraya bermain wajib menjadi dasar bagi guru PAUD dalam membelajarkan anak. Selan itu, hal penting lain yang wajib diperhatikan oleh guru ialah penggunaan media pembelajaran yang semenarik mungkin yang diciptakan dalam proses pembelajaran sehingga anak terlibat lebih aktif. Namun, keterbatasan media pembelajaran di Taman Kanak-Kanak (TKK) di PAUD Terpadu Citra Bakti menjadi salah satu kendala untuk menciptakan pembelajaran yang menyenangkan sesuai dengan karakteristik dan tingkat usia anak.

Media pembelajaran merupakan wahana penyalur pesan pembelajaran yang 
disampaikan oleh guru dan diterima oleh anak sehingga interaksi antara guru dan anak berlangsung baik dalam kegiatan pembelajaran dengan penggunaan media tersebut. Penggunaan media pembelajaran sangat diperlukan dalam proses pembelajaran di TKK karena perkembangan anak TKK berada pada masa konkrit. Hal tersebut artinya bahwa peran media menjadi semakin penting sebagai wahana dalam membelajarkan anak sebab pembelajaran di TKK berdasarkan pada prinsip kekonkritan. Merujuk pada prinsip tersebut harapannya bahwa anak dapat mempelajari sesuatu secara nyata (Badru Zaman, dkk, 2010). Oleh karena itu, dalam menjawabi prinsip kekonkritan pada pembelajaran di TKK, maka pemanfaatan media pembelajaran merupakan sesuatu yang memungkinkan untuk membantu membuat anak dapat belajar. Sebab dengan media pembelajaran, materi pembelajaran dapat tersampaikan dan diterima oleh anak secara efektif.

Pada kegiatan observasi selanjutnya guru masih menggunakan cara yang sama dalam pembelajaran berhitung. Guru memberi latihan sederhana kepada anak dengan cara mengerjakan latihan tersebut di papan tulis yang sebelumnya tentu dicontohkan terlebih dahulu oleh guru. Pemberian reward dalam bentuk bintang diberikan kepada anak yang mau mengerjakan latihan tersebut. Latihan ini dapat dikatakan kurang memberikan efek positif bagi anak sebab setiap kali diminta kesediaan untuk mengerjakan tugas tersebut hanya anak yang sama yang maju, sedangkan anak lain sibuk dengan kesibukannya sendiri. Di samping itu, dari hasil wawancara dengan guru Kelompok B, diketahui bahwa anak-anak kelompok B secara spontan menyatakan kebosanan pada waktu menyelesaikan lembar kerja anak. Hal tersebut menggambarkan bahwa guru perlu menciptakan hal baru bagi anak agar terhindar dari rasa bosan. Namun, guru kewalahan dalam mengatur waktu untuk menciptakan variasi dan media pembelajaran yang menarik dalam kegiatan pembelajaran anak karena dijejali dengan tugas-tugas administrasi.

Pada kegiatan belajar dan mengajar di TKK guru harus mengomunikasikan materi pembelajaran yang disebut tema dan subtema. Penyampaian isi dari tema dan subtema tersebut memerlukan media pembelajaran sebab proses pembelajaran anak TKK sedang dalam masa konkrit. Artinya peran media menjadi hal utama yang wajib disiapkan oleh guru. Meskipun masih banyak guru yang mengganggap bahwa peran 
media dalam proses pembelajaran hanya sebatas alat bantu semata dan boleh diabaikan manakala media itu tidak tersedia di sekolah. Kenyataan ini perlu dihilangkan dari perspektif seorang guru secara khusus guru PAUD karena media merupakan bagian integral dari keseluruhan proses pembelajaran. Proses pembelajaran di TKK tidak akan berjalan efektif tanpa media.

Dari uraian latar belakang diatas, maka dilakukan penelitian berjudul "Pengembangan Media Pembelajaran Apron Hitung Untuk Meningkatkan Kemampuan Berhitung Pada Anak Usia Dini di Kelompok B PAUD Terpadu Citra Bakti."

\section{METODE PENELITIAN}

Penelitian ini mengacu pada jenis penelitian pengembangan research and development dengan menggunakan model pengembangan ADDIE yang dikembangkan oleh Dick and Carry terdiri dari lima tahap proses pengembangan, yaitu Analysis, Design, Develop, Implement and Evaluate. Salah satu fungsi ADDIE yaitu menjadi pedoman dalam membangun perangkat dan infrastruktur program pelatihan yang efektif, dinamis dan mendukung kinerja pelatihan itu sendiri. Model ini dapat digunakan untuk berbagai macam bentuk penelitian produk seperti model, strategi pembelajaran, metode pembelajaran, media dan bahan ajar. Model ADDIE dikembangkan oleh Dick and Carry untuk merancang sistem pembelajaran.

Desain uji coba merupakan hal yang penting dalam tahap uji coba, pada tahap uji coba, produk akan dievaluasi melalui beberapa tahap agar menghasilkan produk yang benar-benar layak untuk pembelajaran anak usia dini. Tahap dalam mengevaluasi media apron hitung antara lain: 1) validasi ahli materi atau ahli media, 2) revisi sesuai masukan ahli materi atau ahli media, 3) uji coba perorangan dengan 2 orang anak, 4) revisi sesuai masukan uji coba perorangan, 5) uji coba kelompok kecil dengan 5 orang anak. 6) revisi produk sesuai masukan uji coba kelompok kecil. Adapun subjek uji coba dalam penelitian ini antara lain: (1) kepala PAUD Terpadu Citra Bakti sebagai ahli materi, (2) Dosen STKIP Citra Bakti sebagai ahli media dan ahli desain pembelajaran, (3) anak PAUD Terpadu Citra Bakti sebagai calon pengguna produk yang berjumlah 5 orang. Pada penelitian ini dilakukan dua tahap uji coba yakni uji coba 
perorangan dan uji coba kelompok kecil.

Berikut merupakan rumus analisis validasi ahli materi, ahli media dan ahli desain pembelajaran.

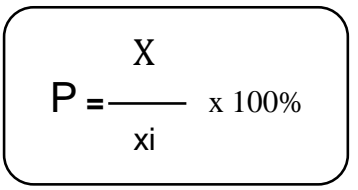

Keterangan:

$\mathrm{P}=$ Persentase skor yang dicari

$\mathrm{X}=$ Jawaban responden dalam satu item

$\mathrm{Xi}=$ Jumlah nilai ideal dalam satu item

$100 \%=$ Konstansta

Rumus analisis penilaian uji coba kelompok kecil dan kelompok besar adalah sebagai berikut.

\section{Keterangan:}

$\mathrm{P}=\frac{\sum \mathrm{x}}{\sum \mathrm{xi}} \times 100 \%$
$\begin{aligned} & \mathrm{P}=\text { Persentase skor yang dicari } \\ & \sum \mathrm{x}=\text { Jumlah keseluruhan jawaban responden dalam satu item } \\ & \sum \mathrm{xi}=\text { Jumlah keseluruhan nilai ideal dalam satu item } \\ & 100 \%=\text { Konstansta }\end{aligned}$

Berdasarkan perhitungan dengan rumus di atas, nilai kemudian dikonversikan menjadi data. Kevalidan yang ditentukan berdasarkan interval penentuan tingkat kevalidan pada tabel berikut.

Tabel 1. Pedoman Konversi Data Kunatitatif ke Dalam Kualitatif Skala Empat

\begin{tabular}{|l|c|c|c|}
\hline No. & Persentase & Nilai & Kategori \\
\hline 1. & $80 \%-100 \%$ & 4 & Sangat Valid \\
\hline 2. & $60 \%-79 \%$ & 3 & Valid \\
\hline 3. & $20 \%-59 \%$ & 2 & Cukup valid \\
\hline 4. & $<20 \%$ & 1 & Kurang Valid \\
\hline
\end{tabular}

Metode observasi, wawancara, angket, dan dokumentasi merupakan metodemetode yang digunakan dalam penelitian ini, sedangkan instrumen penelitian ini adalah panduan observasi, wawancara, angket dan dokumentasi mengenai tujuan pembelajaran aspek kognitif yang akan digunakan berdasarkan media pembelajaran apron hitung yang dikembangkan dan diuji validasinya diantaranya instrumen penilaian ahli materi, instrumen penilaian ahli desain pembelajaran, dan instrumen untuk anak (pengguna produk). 
Data penelitian diperoleh dari ahli materi, ahli media, uji coba perorangan, dan uji coba kelompok kecil. Pengolahan data berbentuk kata-kata dari hasil validasi ahli materi (dosen dan guru), ahli media, dan anak menggunakan teknik analisis deskriptif kualitatif, sedangkan pengolahan data berbentuk angka (skor) yang diperoleh melalui angket menggunakan teknik analisis deskriptif kuantitatif. Proses pengolahan data, baik data deskriptif kualitatif maupun deskriptif kuantitatif tersebut dilakukan untuk mengetahui kelayakan media apron hitung. Analisis data tentang penilaian kelayakan media pembelajaran. Analisis data yang digunakan dalam penelitian ini adalah analisis data secara deskriptif dengan satu variabel yaitu variabel kualitas apron hitung yang telah disusun berdasarkan aspek materi, media, dan desain pembelajaran.

\section{HASIL PENELITIAN DAN PEMBAHASAN}

Model ADDIE yang terdiri dari lima tahap antara lain tahap analisis, tahap desain, tahap pengembangan, tahap implementasi, dan tahap evaluasi dilakukan pada proses penelitian ini. Pada tahap analisis (analyze) dilakukan analisis dari berbagai macam kebutuhan anak mulai dari kurikulum, kebutuhan anak, dan juga kompetensi. Penyesuaian isi materi yang dimuat dalam media pembelajaran apron hitung dilakukan sehingga berhasil menciptakan suasana pembelajaran yang lebih menarik dan semua anak menjadi lebih aktif dalam pembelajaran. Pada analisis kebutuhan anak, kondisi anak diketahui secara detail ditemukan banyak kendala yang dihadapi oleh anak-anak terutama dalam proses pembelajaran. Analisis kompetensi inti dan kompetensi dasar menggunakan kurikulum 2013 yang memuat tentang keterampilan pengetahuan sehingga mendukung penggunaan media apron hitung dalam pembelajaran.

Tahap perancangan (design) dirancang dan didesain model media yang dikembangkan mulai dari pemilihan bahan media, warna media, tampilan media, dan lainnya. Tahap pengembangan (development) dikembangkan produk media pembelajaran apron hitung, dilakukan uji ahli terhadap media yang sudah dikembangkan, kemudian berdasarkan saran dan komentar dari para ahli dilakukan perbaikan terhadap media pembelajaran apron hitung. Berikut disajikan rancangan apron hitung. 


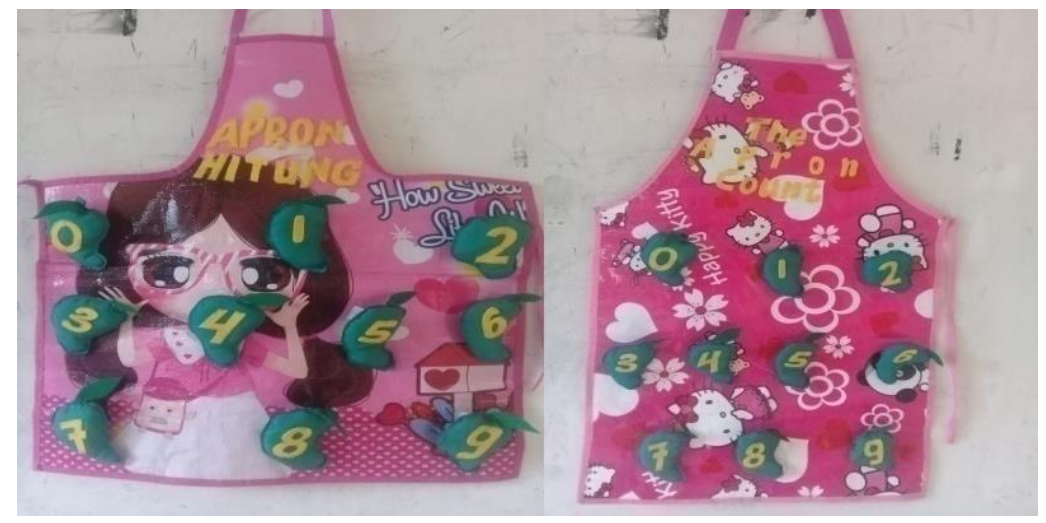

Gambar 1. Tampilan Media Apron Hitung

Pada tahap implementasi dilakukan uji coba produk media apron hitung yang diujicobakan pada anak usia dini kelompok B PAUD Terpadu Citra Bakti yang terdiri dari uji coba perorangan dan uji coba kelompok kecil. Uji coba perorangan dilakukan pada 2 orang anak, sedangkan uji coba kelompok kecil dilakukan pada 5 orang anak kelompok B PAUD Terpadu Citra Bakti.

Dari uji coba-uji coba yang dilakukan memperoleh hasil validasi berikut. Dari ahli materi menilai media pada segi aspek pembelajaran dan isi materi. Penilaian dari ahli materi ini akan dijadikan acuan untuk merevisi produk sebelum dilakukan uji coba lapangan. Ahli materi yang menjadi validator dalam penelitian ini adalah Dorothea Pati, S.Pd. Konsultasi ahli materi dilakukan sebanyak satu kali. Data validasi ahli materi diperoleh dengan cara memberikan penilaian, saran, dan komentar terhadap media dengan mengisi angket yang telah disediakan. Dari aspek pembelajaran: penilaian ini dimaksudkan untuk mengetahui bagaimana penilaian ahli materi mengenai hal yang berhubungan aspek pembelajaran dari media apron hitung untuk kemampuan berhitung anak usia 5-6 tahun. Dengan pedoman penilaian ini diketahui perlu tidaknya dilakukan revisi.

Hasil penilaian tersebut dapat dilihat pada tabel 2 berikut.

Tabel 2. Data Hasil Penilaian Ahli Materi terhadap Aspek Pembelajaran

\begin{tabular}{|c|l|c|c|c|c|}
\hline $\mathbf{N}$ & \multicolumn{1}{|c|}{ Unsur Indikator } & \multicolumn{4}{|c|}{ Skor Penilaian } \\
\cline { 3 - 6 } $\mathrm{O}$ & \multicolumn{1}{|c|}{4} & 3 & 2 & 1 \\
\hline 1 & $\begin{array}{l}\text { Kesesuaian media dengan tingkat } \\
\text { pencapaian perkembangan anak dan } \\
\text { indikator di kurikulum }\end{array}$ & $\sqrt{ }$ & & & \\
\hline
\end{tabular}




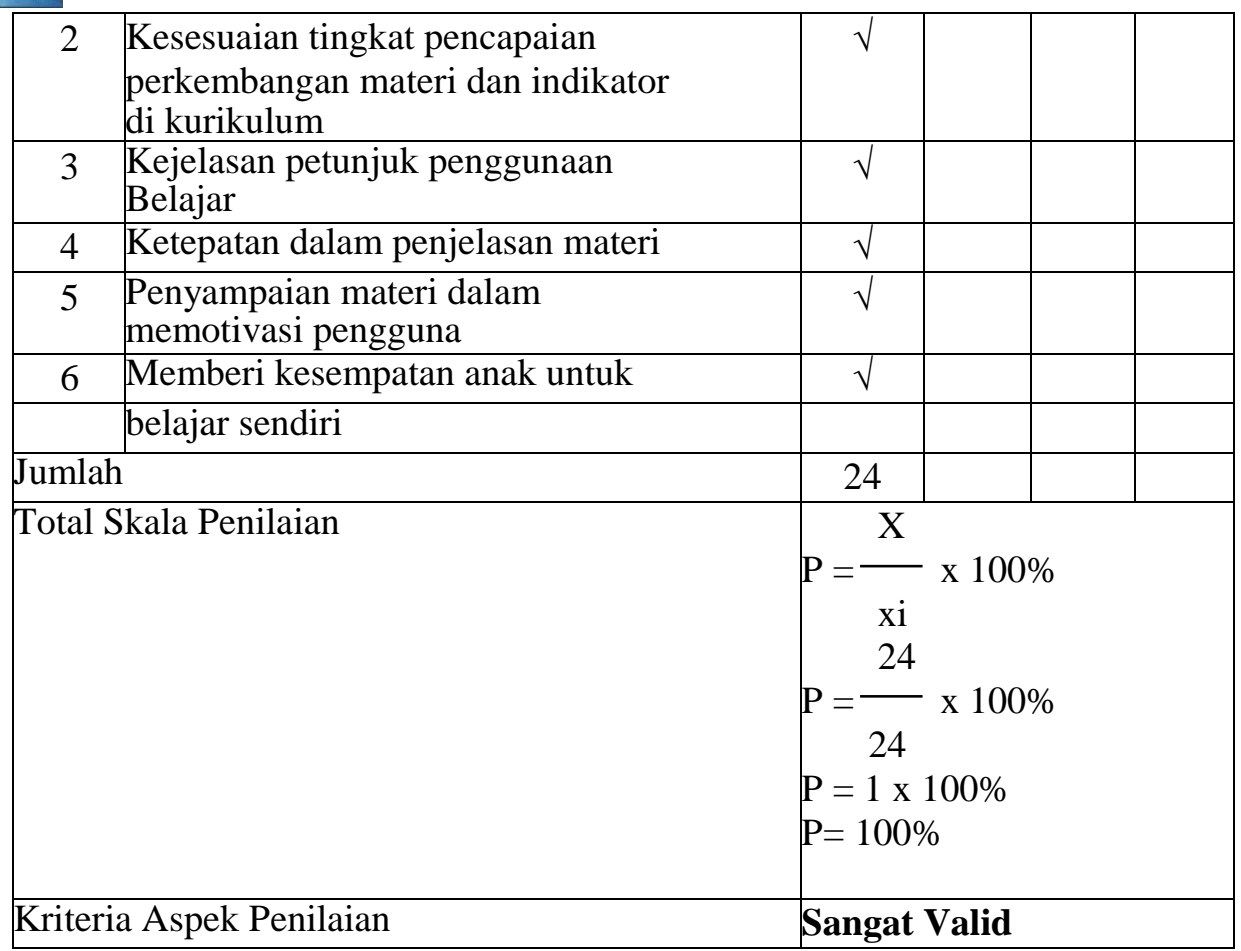

Pada instrumen penilaian yang diberikan kepada ahli materi pada aspek pembelajaran diberikan 6 indikator penilaian untuk dinilai oleh ahli materi dan hasil penilaian mendapatkan skor 4 dari masing-masing indikator sehingga rata-rata hasil yang diperoleh dari 6 indikator yang diukur adalah 100\% dengan kategori sangat valid. Dari aspek isi: penilaian aspek ini untuk mengetahui penilaian ahli materi mengenai hal yang berhubungan dengan aspek isi dari media pembelajaran apron hitung untuk kemampuan berhitung anak usia 5-6 tahun. Dengan pedoman penilaian ini diketahui perlu tidaknya dilakukan revisi. Hasil penilaian tersebut dapat dilihat pada tabel 3 berikut.

Tabel 3. Data Hasil Penilaian Ahli Materi terhadap Aspek Isi

\begin{tabular}{|c|l|c|c|c|c|}
\hline \multirow{2}{*}{$\begin{array}{l}\text { N } \\
\mathrm{O}\end{array}$} & \multicolumn{1}{|c|}{ Unsur Indikator } & \multicolumn{3}{|c|}{ Skor Penilaian } \\
\cline { 2 - 5 } & Kejelasan isi materi & $\sqrt{ }$ & 3 & 2 & 1 \\
\hline 2 & Keluasan dan kedalaman isi materi & $\sqrt{ }$ & & & \\
\hline 3 & $\begin{array}{l}\text { Kejelasan dan kesesuaian bahasa yang di } \\
\text { Gunakan }\end{array}$ & $\sqrt{ }$ & & & \\
\hline 4 & $\begin{array}{l}\text { Kejelasan pemberian informasi pada } \\
\text { apron hitung }\end{array}$ & $\sqrt{ }$ & & & \\
\hline Jumlah & & 16 & & \\
\hline
\end{tabular}




\begin{tabular}{|l|l|}
\hline Total Skala Penilaian & $\mathrm{P}=\frac{\mathrm{X}}{\mathrm{xi}} \times 100 \%$ \\
& $\mathrm{P}=\frac{16}{16} \times 100$ \\
$\mathrm{P}=1 \mathrm{x} 100 \%$ \\
$\mathrm{P}=100 \%$
\end{tabular}

Pada instrumen penilaian yang diberikan kepada ahli materi diberikan 4 indikator penilaian untuk dinilai oleh ahli materi dan hasil penilaian mendapatkan skor 4 dari masing-masing indikator sehingga rata- rata hasil yang diperoleh dari 4 indikator yang diukur adalah 100\% dengan kategori sangat valid. Rata-rata hasil analisis yang diperoleh dari 4 indikator yang diukur adalah 100\% dengan kategori sangat valid. Setelah dilakukan validasi tahap pertama produk yang dikembangkan, maka ahli materi memberikan komentar dan saran. Adapun komentar dan saran yang diberikan oleh ahli materi berupa tanggapan positif terhadap aspek penggunaan dan aspek isi pada media apron hitung, kesesuaian media dengan tingkat pencapaian perkembangan anak, dan kejelasan petunjuk penggunaan media dalam pembelajaran sehingga melalui tanggapan ahli materi tersebut, maka media apron hitung layak diujicobakan tanpa revisi.

Hasil validasi atau penilaian dari ahli media ini akan dijadikan acuan revisi media sebelum media diujicobakan pada anak. Ahli media yang menjadi validator pada penelitian ini adalah Ferdinandus Bate Dopo, S.Fil., M.Pd yang memiliki kompetensi bidang media pembelajaran anak usia dini. Penilaian ahli media bertujuan untuk mengetahui hal yang menyangkut tampilan dari media apron hitung untuk kemampuan berhitung anak usia 5-6 tahun. Data hasil penilaian aspek tampilan dapat dilihat pada tabel 4 sebagai berikut.

Tabel 4. Skor Penilaian oleh Ahli Media

\begin{tabular}{|c|l|c|c|c|c|}
\hline N & \multicolumn{1}{|c|}{ Unsur Indikator } & \multicolumn{5}{|c|}{ Skor Penilaian } \\
\cline { 3 - 6 } O & & 4 & 3 & 2 & 1 \\
\hline 1 & Kesesuaian pemilihan background pada apron & $\sqrt{ }$ & & & \\
\hline 2 & Kesesuaian proporsi warna buah & $\sqrt{ }$ & & & \\
\hline 3 & Kemenarikan bentuk buah & $\sqrt{ }$ & & & \\
\hline
\end{tabular}




\begin{tabular}{|c|l|c|l|l|}
\hline 4 & Kesesuaian pemilihan jenis angka & $\sqrt{ }$ & & \\
\hline 5 & Kesesuaian pemilihan ukuran angka & $\sqrt{ }$ & & \\
\hline 6 & Kemenarikan sajian media apron hitung & $\sqrt{ }$ & & \\
\hline Jumlah & 24 \\
\hline
\end{tabular}

Pada instrumen penilaian yang diberikan kepada ahli media diberikan 6 indikator penilaian untuk dinilai oleh ahli media dan hasil penilaian mendapatkan skor 4 dari masing-masing indikator sehingga rata-rata hasil yang diperoleh dari 4 indikator yang diukur adalah $100 \%$ dengan kategori sangat valid.

Setelah dilakukan validasi produk yang dikembangkan maka ahli media memberikan komentar dan saran. Adapun komentar dan saran yang diberikan oleh ahli media berupa tanggapan positif terhadap media pembelajaran apron hitung antara lain kreatif, menarik, sesuai dengan kebutuhan anak, bagus untuk digunakan pada anak usia dini. Ahli media melihat bahwa media apron hitung sudah memenuhi karakteristik perkembangan anak juga masuk pada tiap indikator perkembangan pada anak kemudian meminta kesediaan untuk memperbanyak media. Melalui tanggapan ahli media tersebut, maka media apron hitung layak diujicobakan tanpa revisi.

Pada penilaian ahli desain pembelajaran ini akan dijadikan acuan revisi penggunaan media sebelum media ini diujicobakan pada anak. Ahli desain yang menjadi validator pada penelitian ini adalah Dr. Dek Ngurah Laba Laksana, M.Pd yang memiliki kompetensi bidang desain pembelajaran anak usia dini. Penilaian desain pembelajaran bertujuan untuk mengetahui penilaian ahli desain terhadap segala hal yang berhubungan dengan aspek penggunaan dari produk ini setelah dilakukan revisi tahap pertama.

Berikut adalah pedoman dalam penggunaan media pembelajaran apron hitung. Tahap awal: Guru menjelaskan kepada anak tentang tema pembelajaran dan cara 
menggunakan apron hitung. Apron hitung dikenakan pada anak (berukuran kecil) dan pada guru (berukuran besar). Anak yang mengenakan apron hitung dengan cara mengalungkan apron di leher kemudian mengikat tali yang berada disamping kiri dan kanan media apron hitung ke belakang lalu anak diminta untuk berdiri di depan kelas dan menghadap teman-tema lainnya. Setelah guru menjelaskan cara bermain dengan menggunnakan apron hitung, anak diminta satu persatu untuk memasangkan angka apron sembari guru menyebutkan angka 0-9.

Tahap selanjutnya: Setelah semua anak mendapatkan giliran untuk memasangkan angka apron, selanjutnya guru meminta kepada anak yang belum dapat memasangkan angka apron sesuai urutan atau anak yang belum mengenal angka 0-9 untuk memasangkan ulang sesuai dengan petunjuk dan bimbingan yang diberikan oleh guru sampai anak tersebut mampu melakukannya. Setelah semua anak mampu memasangkan angka dan berhitung dengan baik, guru mengajak anak untuk bermain ke tahap berikutnya, yaitu dengan menghilangkan salah satu angka pada apron hitung kemudian meminta anak untuk menyebutkan angka yang hilang tersebut, lakukan secara bergantian dengan menghilangkan angka yang berbeda. Data hasil dari penilaian aspek penggunaan oleh ahli desain dapat dilihat pada tabel 5 sebagai berikut.

Tabel 5. Skor Penilaian Aspek Tampilan oleh Ahli Desain Pembelajaran

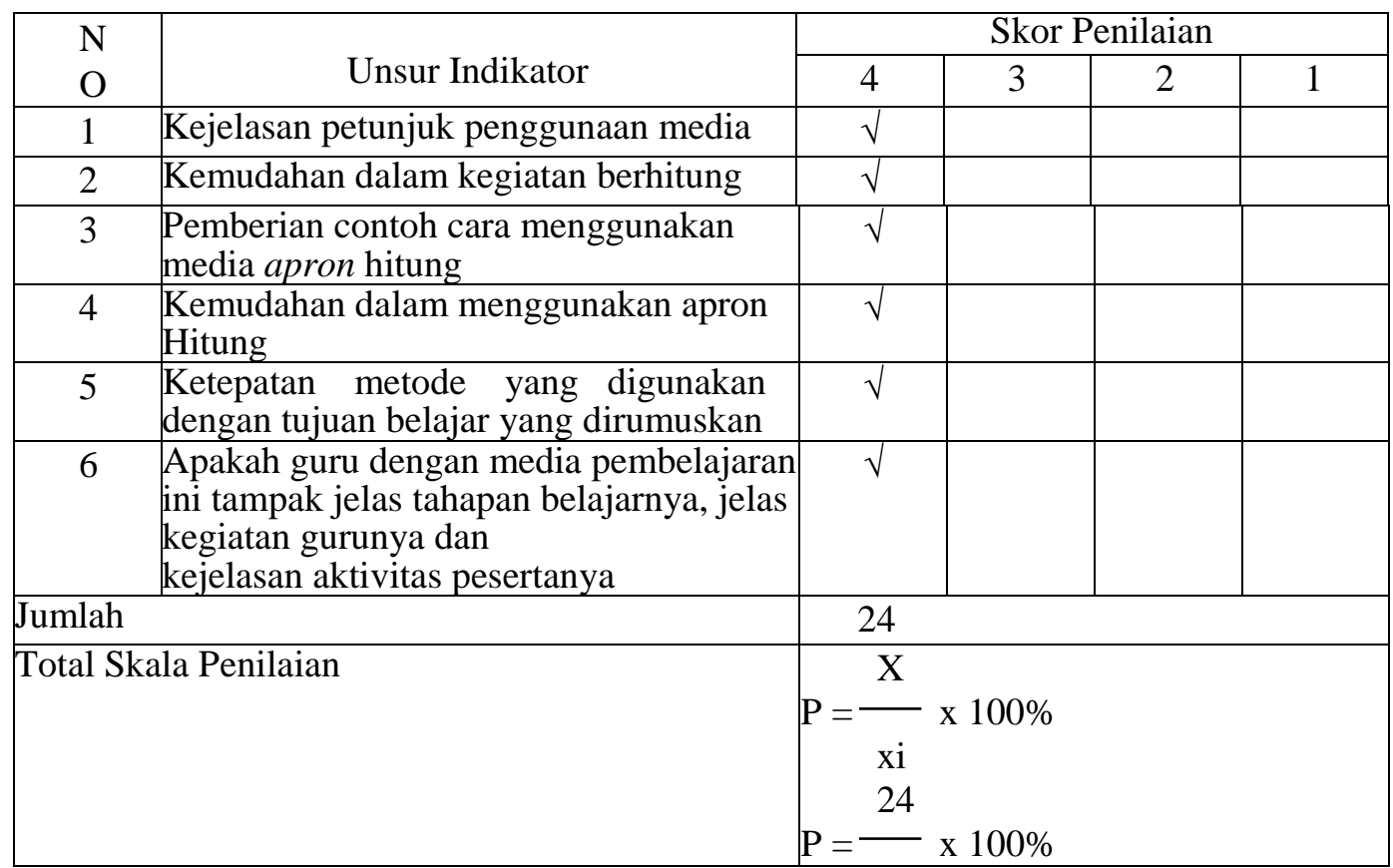




\begin{tabular}{|c|c|}
\hline & \begin{tabular}{l}
\multicolumn{1}{c}{24} \\
$\mathrm{P}=1 \times 100 \%$ \\
$\mathrm{P}=100 \%$
\end{tabular} \\
\hline Kriteria Apek Penilaian & Sangat Valii \\
\hline
\end{tabular}

Pada instrumen penilaian yang diberikan kepada ahli desain pembelajaran diberikan 6 indikator penilaian dan mendapatkan skor 4 dari masing-masing indikator sehingga rata-rata hasil yang diperoleh dari 6 indikator yang diukur adalah $100 \%$ dengan kategori sangat valid.

Setelah dilakukan validasi produk yang dikembangkan, maka ahli desain pembelajaran memberikan komentar dan saran. Adapun komentar dan saran yang diberikan oleh ahli desain pembelajaran berupa tanggapan positif terhadap media pembelajaran apron hitung, yakni tidak perlu melakukan wawancara kepada anak cukup dengan observasi sehingga melalui tanggapan ahli desain pembelajaran tersebut, maka media apron hitung layak diujicobakan tanpa revisi.

Komentar dan saran yang diberikan oleh ahli dan anak terhadap media pembelajaran apron hitung yang dikembangkan antara lain: (1) Ahli Materi. Komentar dan tanggapan yang diberikan ahli materi terhadap aspek penggunaan dan aspek isi adalah kesesuaian media dengan tingkat pencapaian perkembangan anak, dan kejelasan petunjuk penggunaan media dalam pembelajaran sehingga melalui tanggapan ahli materi tersebut, maka media apron hitung layak diujicobakan tanpa revisi, (2) Ahli Media. Komentar dan saran yang diberikan ahli media adalah berupa tanggapan positif terhadap media pembelajaran apron hitung, yaitu kreatif, menarik, sesuai dengan keinginan anak, bagus untuk digunakan pada anak usia dini dan meminta kesediaan untuk memperbanyak media sehingga melalui tanggapan ahli media tersebut, maka media apron hitung layak diujicobakan tanpa revisi. (3) Ahli Desain Pembelajaran. Komentar dan saran dari ahli desain pembelajaran adalah tidak perlu melakukan wawancara kepada anak cukup dengan observasi sehingga melalui tanggapan ahli desain pembelajaran tersebut, maka media apron hitung layak diujicobakan tanpa revisi. (4) Tanggapan Anak Sebagai Calon Pengguna Produk. Tanggapan positif dari anak sebagai pengguna produk dilihat dari hasil wawancara dan kegiatan pembelajaran. 
Tahap evaluasi yaitu hasil revisi dari uji coba yang dilakukan. Setelah media pembelajaran ini dihasilkan kemudian melalui uji coba yang dilakukan oleh peneliti dengan tujuan untuk meminimalkan kesalahan. Pada tahap akhir adalah pengguna dalam bentuk apron hitung. Setelah produk awal selesai dibuat, maka dilakukan validasi terhadap ahli materi dan ahli media.

Pada tahap analisis dianalisis kurikulum, kebutuhan anak dan analisis kompetensi. Pada tahap analisis kurikulum dikaji tentang kurikulum yang digunakan di sekolah PAUD Terpadu Citra Bakti yang menggunakan kurikulum 2013 PAUD yang tertuang dalam Permendikbud No. 146 tahun 2014. Dengan kajian difokuskan untuk aspek perkembangan kognitif anak usia dini dalam standar nasional PAUD No. 137 yang memuat tentang Standar Tingkat Pencapaian Perkembangan Anak (STPPA). Tahap analisis kebutuhan anak, dilakukan analisis kebutuhan anak pada siswa kelompok B PAUD Terpadu Citra Bakti. Kemudian diciptakan media pembelajaran yang edukatif, kreatif, dan menarik yaitu media apron hitung, sehingga anak menjadi tertarik dan terlibat dalam proses pembelajaran dan lebih aktif. Pada tahap analisis kompetensi, dengan menggunakan K-I (3) yang memuat tentang keterampilan pengetahuan dan KD 3.5, 3.6, dan 3.8 yang digunakan sebagai acuan dalam penggunaan media dalam proses pembelajaran.

Tahap perancangan yang dilakukan adalah membuat model dasar media apron hitung berupa celemek atau baju koki dan menentukan tema dan sub-sub tema yang sesuai dengan media pembelajaran. Tema tanaman dan sub-sub tema tanaman mangga ditetapkan sebagai bahan media penelitian. Media apron hitung berukuran 30 x $30 \mathrm{~cm}$ berbentuk seperti celemek yang terbuat dari karung berwarna dan bergambar, berbentuk buah mangga yang terbuat dari kain warna hijau dan diisi dengan kapas, direkatkan pada kain flanel, dan ditempelkan angka 0-9. Setelah media pembelajaran apron hitung selesai dirancang kemudian dipublikasi. Setelah proses publikasinya selesai, media apron hitung siap digunakan.

Media pembelajaran apron hitung terdiri atas beberapa bagian utama seperti segi tampilan dan aturan permainan. Penilaian oleh beberapa ahli antara lain ahli materi, ahli media, ahli desain dan anak sebagai calon pengguna produk dilakukan setelah media pembelajaran apron hitung ini dihasilkan. Dari lembar kuisioner yang 
dinilai oleh ahli dan guru sebagai pengganti anak terdapat beberapa komentar positif mengenai media pembelajaran yang dikembangkan. Komentar tersebut digunakan sebagai penguatan dalam penelitian media pembelajaran apron hitung. Pada ahli materi mendapatkan skor $100 \%$ dengan kategori kelayakan "sangat valid" masingmasing penilaian terdiri dariaspek pembelajaran dan aspek isi, pada ahli media mendapatkan skor 100\% dengan kategori kelayakan"sangat valid", dan ahli desain pembelajaran mendapatkan skor 100\% dengan kategori kelayakan "sangat valid."

Tahap implementasi dilakukan uji coba perorangan dan uji coba kelompok kecil produk media apron hitung pada anak usia dini kelompok B PAUD Terpadu Citra Bakti. Pada uji coba perorangan respon anak sangat antusias dan diberi 5 indikator penilaian dalam bentuk pertanyaan kepada 2 orang anak dan mendapatkan skor 4 dari masing- masing komponen sehingga rata-rata hasil yang diperoleh dari 5 indikator yang diukur adalah 100\% dengan kategori sangat valid. Pada uji coba kelompok kecil respon anak positif dan diberi5 indikator penilaian dalam bentuk pertanyaan kepada 5 orang anak dan mendapatkan skor 4 dari masing-masing indikator sehingga rata-rata hasil yang diperoleh dari 5 indikator yang diukur adalah $100 \%$ dengan kategori sangat valid. Jawaban atas pertanyaan-pertanyaan yang diberikan diisi oleh peneliti atas kesepakatan dengan guru kelas B, dikarenakan anak usia 5-6 tahun belum bisa mengisi lembaran.Selain telah memenuhi kriteria perancangan media pembelajaran seperti yang dikemukakan Prawastiningtyas (2015), media pembelajaran apron hitung yang dikembangkan ini telah memenuhi persyaratan kelayakan produk penelitian.

Suatu produk media pembelajaran yang dikembangkan dikatakan memiliki derajat validitas atau kualitas yang baik dan layak untuk digunakan di sekolah, jika minimal kriteria validitas yang dicapai adalah valid. Berdasarkan hasil analisis data di atas, diperoleh bahwa media pembelajaran apron hitung yang dikembangkan berada pada kategori sangat valid. Hal ini dapat dilihat dari tabel hasil uji coba ahli materi, ahli media, ahli desain pembelajaran, dan anak sebagai calon pengguna produk. Komentar dan saran dari masing- masing validator yang diperoleh dari lembar instrumen digunakan peneliti sebagai bahan penguatan terhadap penggunaan media pembelajaran apron hitung. Adapun hasil penelitian media pembelajaran 
apron hitung, telah diuraikan pada penjelasan sebelumnya.

Berdasarkan hasil analisis data tersebut, maka dapat disimpulkan bahwa media pembelajaran yang dikembangkan yaitu apron hitung layak digunakan oleh anak PAUD Terpadu Citra Bakti untuk meningkatkan kemampuan berhitung pada anak kelompok B dibuktikan dengan hasil uji coba kelompok kecil yang terdapat pada instrumen pertanyaan yang diberikan oleh peneliti, "Apakah media pembelajaran apron hitung dapat meningkatkan pemahaman anak tentang mengenal angka dan berhitung?" Indikator tersebut menjadi poin penting dalam proses penelitian untuk menghasilkan media pembelajaran apron hitung sehingga dinyatakan layak untuk digunakan. Hal ini juga dilihat dari respon anak dalam kegiatan pembelajaran dimana anak sudah mengenal angka dan mampu berhitung secara mandiri.

Berdasarkan kesimpulan tersebut, maka rumusan masalah dalam penelitian ini telah terjawab. Media pembelajaran apron hitung berhasil dikembangkan dengan perolehan kriteria validitas hasil uji coba produk sangat valid. media pembelajaran apron hitung yang dikembangkan juga sudah sesuai dengan karakteristik anak PAUD Terpadu Citra Bakti karena media pembelajaran yang dikembangkan berbasis tema tanaman dan sub-sub tema tanaman mangga.

\section{SIMPULAN DAN SARAN}

Berdasarkan paparan pada bagian pembahasan, maka dapat disimpulkan bahwa media pembelajaran berupa apron hitung yang dikembangkan layak digunakan dalam pembelajaran berhitung oleh anak dengan menyesuaikan materi dengan karakteristik anak, mudah digunakan dalam pembelajaran, dan sesuai dengan kurikulum. dengan memperhatikan aspek materi (pembelajaran dan isi), dan aspek media juga aspek desain pembelajaran. Hal tersebut dapat dihasil dari validasi ahli media apron hitung validasi aspek pembelajaran memperoleh skor $100 \%$ (kriteria sangat valid), aspek isi memperoleh skor 100\% (kriteria sangat baik), dan aspek tampilan memperoleh skor $100 \%$ (kriteria sangat valid), dan aspek pengguna 100\% (kriteria sangat valid). Validasi media apron hitung dilakukan terhadap anak PAUD Terpadu Citra Bakti. Dengan menggunakan media pembelajaran apron hitung dalam proses belajar mengajar dapat mengembangkan keterampilan berhitung pada anak. Pada kegiatan uji 
coba perorangan dari pertanyaan yang diberikan mendapatkan skor 100\% (kriteria sangat valid) dan uji coba kelompok kecil mendapatkan skor 100\% (kriteria sangat valid).

Beberapa saran dapat disampaikan sesuai dengan hasil penelitian antara lain: 1) Bagi kepala sekolah. Kepala sekolah perlu memberikan pemahaman kepada guru tentang pentingnya penggunaan media dalam proses pembelajaran dan melibatkan anak secara langsung dalam pemanfaatan media pembelajaran pada setiap kegiatan pembelajaran, 2) Bagi guru TKK. Guru TKK perlu berkreasi dalam menghasilkan atau membuat media pembelajaran untuk mendukung dan memudahkan kegiatan pembelajaran mengingat masa anak usia dini adalah masa konkrit. Di samping itu, guru perlu memanfaatkan apron hitung yang dikembangkan sebagai media dalam pembelajaran berhitung di kelas, dan 4) Bagi peneliti selanjutnya. Peneliti selanjutnya perlu menguji efektivitas media apron hitung yaitu dengan melanjutkan penelitian ke tahap implementasi.

\section{DAFTAR PUSTAKA}

Ahmad Susanto. (2011). Perkembangan Anak Usia Dini. Jakarta: Prenada Media Group.

Anggani Sudono. (2010). Sumber Belajar dan Alat Permainan (Untuk Anak Usia Dini). Jakarta: PTGrasindo.

Badru Zaman, Asep Hery Hernawan \& Cucu Eliyawati. (2010). Media dan Sumber Belajar TIK. Jakarta: Universitas Terbuka.

Efrida Ita. (2018). Manajemen Pembelajaran Pendidikan Anak Usia Dini di TK Rutosoro Kecamatan Golewa Kabupaten Ngada Flores Nusa Tenggara Timur.

Jurnal Dimensi Pendidikan dan Pembelajaran.No 1. 45-52.

Hamruni Yuliani. (2014). Pengembangan Media Pohon Hitung Berbais Paikem

Terhadap Kemampuan Berhitung Anak Usia 5-6 Di TK Education 21 Kulim

Pekanbaru. Pekanbaru. FKIP UR.

Peraturan Menteri Pendidikan dan Kebudayaan Republik Indonesia Nomor 137

Tahun 2014 Tentang Standar Nasional Pendidikan Anak Usia Dini.

Peraturan Menteri Pendidikan dan Kebudayaan Republik Indonesia Nomor 146

Tahun 2014 Tentang Kurikulum 2013 Pendidikan Anak Usia Dini.

Prawastiningtyas. (2015). Pengembangan Media Apron Hitung Untuk Meningkatkan Kemampuan Berhitung Anak Usia 5-6 Tahun Di TK Pkk

Kartini Padokan Kidul Tirtonirmolo Kasihan Bantul. Yogyakarta: UNY. Sugiyono. (2007). Metode Penelitian Pendidikan. CV. Alfabeta: Bandung. Suyanto. (2005). Dasar-Dasar Pendidikan Anak Usia Dini. Yogyakarta: Hikayat. 
Al Athfaal: Jurnal Ilmiah Pendidikan Anak Usia Dini

Vol.2 No.2 (2019) 14-31

p-ISSN : 2622-5484

http://ejournal.radenintan.ac.id/index.php/al-athfaal

e-ISSN : 2622-5182

Desember 2019

Undang-Undang Nomor 20 Tahun 2003 tentang Sistem Pendidikan Nasional. 